\title{
SEJARAH USHUL FIQH MASUK DI INDONESIA
}

\section{Rahmawati $^{1}$}

\begin{abstract}
Abstrak
Sejak periode awal sejarah Islam, perilaku kehidupan kaum muslimin dalam keseluruhan aspeknya telah diatur oleh hukum Islam. Aturan-aturan ini, pada esensinya, bersifat religius. Oleh karena itu, dalam pembinaan dan pengembangannya, selalu diupayakan berdasarkan kepada al-Qur'an, sebagai wahyu Illahi yang terakhir, yang pengaplikasiannya untuk sebagian besar dicontohkan dan dioperasionalkan oleh sunnah Rasulullah saw. Dalam perkembangan selanjutnya, Islam yang sudah menyebar sedemikian luasnya, pluralitas masyarakat tidak dapat dihindarkan lagi, masalah yang timbul pun tidak kalah kompleksnya yang menuntut upaya ijtihad yang lebih komprehensip bagi segenap pengikutnya, khususnya para intelektual muslim yang memiliki tanggung jawab yang paling berkompeten dalam hal tersebut. Hal demikian dilakukan untuk lebih mengaktualisasikan misi Islam yang bersifat elastis dan tidak ada unsur pemaksaan bagi manusia.

Dalam tulisan ini akan dipaparkan masalah awal penyusunan ilmu ushul fiqh (dan kemudian menjadi salah satu dari bagian displin ilmu) yang telah dipelopori Imam Syafi'i dalam menyusun ilmu tersebut secara sistematis, yang dengan kecerdasannya, ia mampu menangkap fenomena yang ada dari perkembangan ilmu ushul fiqh dari periode sebelumnya dan diaplikasikan dalam karyanya yang konkrit.
\end{abstract}

Kata Kunci: Ushul Fiqh, Sejarah, Disiplin ilmu

\section{A. PENDAHULUAN}

Ilmu Ushul fiqh merupakan sebuah disiplin ilmu yang muncul belakangan dibandingkan ilmu-ilmu agama yang lain. Yang mana fungsinya adalah untuk mengatur interaksi sosial, dan juga menyelesaikan berbagai permasalahan yang tidak secara eksplisit ada di dalam Al-Qur'an. Pada qodi, hakim dan ulama terdahulu dalam

\footnotetext{
${ }^{1}$ Rahmawati adalah Tenaga Pengajar Pada STAIN Manado Jurusan Syari’ah.
} 
menentukan sebuah hukum biasanya disesuaikan dengan pemikiran dan ijtihad serta sesuai dengan adat-istiadat yang berlaku di daerah dimana permasalahan itu terjadi. ${ }^{2}$

Sebagaimana yang dikemukakan para ahli ushul fiqh, ilmu ini merupakan kunci dalam memahami hukum syara'. Kesalahan dalam menukilkan suatu pernyataan atau metode, akan membawa kepada kesalahan pada hasil yang akan dicapai. Perbedaan pandangan dalam metode atau hasil (produk) ilmu ushul fiqh, bukanlah suatu kelemahan ilmu ini, karena perbedaan pandangan itu menunjukkan kebebasan berpikir para ahli dalam mengemukakan pendapatnya.

Tidak jarang, perbedaan metode atau teori dalam memahami dalil, tidak berpengaruh sama sekali terhadap hasil yang dicapai. Karna berbagai teori yang digunakan para pakar ushul fiqh tujuannya hanya satu, yaitu untuk kemaslahatan manusia. Disamping itu, kaidah-kaidah ushul fiqh bukanlah suatu yang mudah dipahami, karena untuk menetapkan dan menerapkan suatu kaidah, para pakar ushul fiqh mengemukakan berbagai analisis mendalam sehingga untuk menukilkannya ke dalam bahasa Indonesia merupakan kesulitan yang biasa dihadapi oleh pakar-pakar ushul fiqh Indonesia. ${ }^{3}$

Namun yang terpenting dalam pengkajian ilmu ushul fiqh dan kaidah-kaidahnya bukanlah merupakan bahasan dan kaidah yang ta'abbudiyyah (bersifat ibadah), tetapi ia hanyalah merupakan sejumlah alat dan sarana yang digunakan oleh pembuat hukum untuk memelihara kemaslahatan umum dan berdiri pada ketentuan ilahi dalam penetapan syari,atnya, dan dipergunakan oleh seorang hakim dalam mencari keadilan di dalam putusannya dan menetapkan undang-undang sebagaimana mestinya. Hal-hal ini tidaklah menjadi kekhususan daripada nash syara' dan hukum syara' ${ }^{4}$

8)

${ }^{2}$ Abd. Al-Majid al-Syarfi, Al-Islam al-Hadasah, cet. Ke-3 (Tunisia: Dar Al-Janub li Al-Nasyr, 199

${ }^{3}$ Nasrun Harun Ushul Fiqh 1 (Jakarta: Logos Wacana Ilmu: 1997), hlm. xiii.

${ }^{4}$ Abdul Wahhab Khallaf, Ilmu Uhsul Figh (semarang: Dina Utama: 1994), hlm. 12. 
Berbicara tentang Ushul Fiqh, tidak terlepas dari 4 hal yaitu apa, dimana, bagaimana dan oleh siapa. Empat pertanyaan ini akan penulis jawab dalam tulisan ini, walaupun dengan keterbatasan leteratur dan mencoba mengulas balik tentang ushul fiqh dalam sejarahnya hadir di Indonesia.

\section{B. PENGERTIAN USHUL FIQH}

Kata "ushul fiqh" adalah kata ganda yang terdiri dari kata "ushul" dan kata "fiqh" secara etimologi berarti "paham yang mendalam". Kata ini muncul sebanyak 20 kata dalam al-Quran dengan arti paham itu, umpamanya dalam surat al-Kahfi (18): 93:

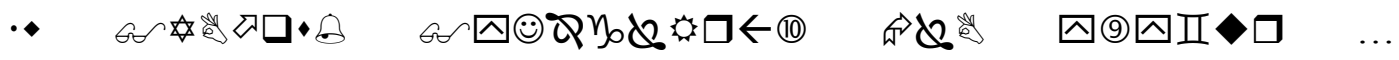

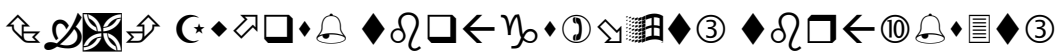 ....dia mendapati di hadapan kedua bukit itu suatu kaum yang hampir tidak mengerti pembicaraan.}

Arti yafqahûna dalam ayat itu: "mereka memahami”. Arti fiqih dari segi istilah hukum sebenarnya tidak jauh berbeda dari artian etimologi sebagaimana disebutkan di atas yaitu: "Ilmu tentang hukum-hukum syara' yang bersifat amaliah yang digali dan dirumuskan dari dalil-dalil tafsili".

Kata "ushul" yang merupakan jamak dari kata "ashal" secara etimologi berarti "sesuatu yang menjadi dasar bagi yang lainnya". Arti etimologi ini tidak jauh dari maksud definitif dari kata "ashal"(أصل) tersebut karena ilmu ushul itu adalah suatu ilmu yang kepadanya didasarkan "fiqh". Dengan demikian "ushul fiqh" secara istilah teknik hukum berarti: "Ilmu tentang kaidah-kaidah yang membawa kepada usaha merumuskan hukum syara' dari dalilnya yang terinci," atau dalam artian sederhana adalah: "Kaidahkaidah yang membawa kepada usaha merumuskan hukum syara' dari dalilnya yang 
terinci," atau dalam artian sederhana adalah: "Kaidah-kaidah yang menjelaskan caracara mengeluarkan hukum-hukum dari dalil-dalilnya". ${ }^{5}$

Para ulama ushul menjelaskan pengertian ushul fiqh dari dua sudut pandang. Pertama dari pengertian kata ushul dan fiqh secara terpisah, kedua dari sudut pandang ushul fiqh sebagai disiplin ilmu tersendiri.

Ushul Fiqh ditinjau dari 2 kata yang membentuknya

Al-Ushul

Al-ushul adalah bentuk jamak dari al-ashl yang secara etimologis berarti mayubna 'alaihi ghairuhu (dasar segala sesuatu, pondasi, asas, atau akar).

Tidakkah kamu memperhatikan bagaimana Allah telah membuat perumpamaan kalimat yang baik seperti pohon yang baik, ashluha (akarnya) teguh dan cabangnya (menjulang) ke langit. (Ibrahim: 24)

Sedangkan menurut istilah, kata al-ashl berarti dalil, misalnya: para ulama mengatakan:

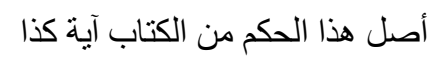

(Dalil tentang hukum masalah ini ialah ayat sekian dalam Al-Qur'an).

Jadi Ushul Fiqh adalah dalil-dalil fiqh. Dalil-dalil yang dimaksud adalah dalildalil yang bersifat global atau kaidah umum, sedangkan dalil-dalil rinci dibahas dalam ilmu fiqh.

Ushul Fiqh sebagai disiplin ilmu

${ }^{5}$ Amir Syarifuddin, Ushul Fiqh Jilid 1 (Jakarta: Logos Wacana Ilmu: 1997), hlm. 35. 
Ushul Fiqh sebagai sebuah disiplin ilmu tersendiri didefinisikan oleh $\mathrm{Al}$ Baidhawi, salah seorang ulama mazhab Syafi'i dan Jumhur ulama:

$$
\text { معرفة دلائل الفقه إجمالا وكيفية الاستفادة منها وحال المستفيد }
$$

(Memahami dalil-dalil fiqh secara global, bagaimana menggunakannya dalam menyimpulkan sebuah hukum fiqh (bagaimana berijtihad), serta apa syaratsyarat seorang mujtahid).

\section{Penjelasan Definisi}

Contoh dalil yang bersifat global: dalil tentang sunnah sebagai hujjah (sumber hukum), dalil bahwa setiap perintah pada dasarnya menunjukkan sebuah kewajiban, setiap larangan berarti haram, bahwa sebuah ayat dengan lafazh umum berlaku untuk semua meskipun turunnya berkaitan dengan seseorang atau kasus tertentu, dan lain-lain.

Yang dimaksud dengan menggunakan dalil dengan benar misalnya: mengetahui mana hadits yang shahih mana yang tidak, mana dalil yang berbicara secara umum tentang suatu masalah dan mana yang menjelaskan maksudnya lebih rinci, mana ayat/hadits yang mengandung makna hakiki dan mana yang bermakna kiasan, bagaimana cara menganalogikan (mengkiaskan) suatu masalah yang belum diketahui hukumnya dengan masalah lain yang sudah ada dalil dan hukumnya, dan seterusnya.

Kemudian dibahas pula dalam ilmu ushul apa syarat-syarat yang harus dipenuhi oleh seorang mujtahid untuk dapat mengambil kesimpulan sebuah hukum dengan benar dari dalil-dalil Al-Qur'an maupun sunnah Rasulullah saw. ${ }^{6}$

Definisi ini menggambarkan bahwa yang menjadi obyek kajian para ulama ushul fiqh adalah dalil-dalil yang bersifat ijmâlil/ اجما لى (global), seperti kehujajahan ijmâ' dan qiyâs. Ushul fiqh juga membahas bagaimana cara mengistinbatkan hukum dari dalil-

\footnotetext{
${ }^{6}$ hhtp://dolla.blogsome.com, akses 31 Desember 2009.
} 
dalil, seperti kaidah mendahulukan hadist mutawatir dari hadist ahad dan mendahulukan nash dari zhâhir. Dalam ushul fiqh dibahas pula syarat-syarat orang yang menggali hukum dari dalil. Untuk yang disebut terakhir ini, menurut ulama syafi'iyyah, dalam pembahasan ushul fiqh juga dibahas syarat-syarat mujtahid dan persoalan yang berkaitan dengan masalah taklid. ${ }^{7}$

Jumhur ulama ushul fiqh yang terdiri atas ulama Hanafiyyah, Malikiyyah dan Hanabilah mendefinisikan ushul fiqh:"Mengetahui kaidah-kaidah kulli (umum) yang dapat digunakan untuk mengistinbatkan hukum-hukum syara' yang bersifat amaliah melalui dalil-dalilnya yang rinci", 8

Jadi ushul fiqh menurut istilah syara, adalah: Pengetahuan mengenai berbagai kaidah dan bahasan yang menjadi sarana untuk mengambil hukum-hukum syara' mengenai perbuatan manusia dari dalil-dalilnya yang terinci. Atau ushul fiqh adalah: himpunan kaidah dan bahasan yang menjadi sarana untuk mengambil dalil hukumhukum syara' mengenai perbuatan manusia dari dalil-dalil yang terinci. ${ }^{9}$

\section{PERKEMBANGAN USHUL FIQH DI INDONESIA}

Sebelum masuk ke dalam topik inti, sedikit menilik bagaimana cara yang diterapkan oleh para pakar ushul fiqh di Indonesia dalam menjabarkan apa yang ada di kitab-kitab yang bertuliskan bahasa Arab ke dalam bahasa Indonesia.

Transliterasi merupakan problem "terbesar" dalam proses editing buku atau kitabkitab yang bertuliskan bahasa Arab. Terlebih lagi jika berhadapan dengan kata AlQur'an, sehingga diperlukan ushul fiqh (epistemologi) transliterasi. Hingga akhir tahun 1970-an, transliterasi ini didominasi “anak-anak pembaharu” lulusan Timur Tengah.

\footnotetext{
${ }^{7}$ Nasrun Harun, Ushul Fiqh 1..., hlm. 3.

${ }^{8}$ Ibid.

${ }^{9}$ Abdul Wahhab Khallaf, Ilmu Uhsul Fiqh...,hlm. 2.
} 
Untuk mempermudah pembaca yang kurang mengenal bahasa Arab, kata Alquran mereka tulis latin menjadi Al-Qur'an, Al Qur'aan dan Al-Qur'an. Disini ada dua nilai "sakral" yang terdapat dalam huruf A sebagai bagian dari kata sandang al dan pada huru Q sebagai nama diri. Untuk menghilangkan mafsadat-mafsadat teknis, yang belum terjangkau teknologi cetak Indonesia, mereka menggunakan huruf ganda untuk menunjukkan tanda panjang (maad).

Hasil Ijtihad ini mulai terusik setelah "anak-anak Orientalis” pulang ke Indonesia, khususnya diawal tahun 1980-an. Ini diperkuat dengan pengaruh pengindonesiaan naskah-naskah keislaman dari bahasa Inggris, yang diterjemahkan oleh orang-orang yang tidak mengusai bahasa Arab."Anak-anak Orientalis" ini "membidahkan" transliterasi "kembali kepada Quran" dengan memperkenalkan "Ijtihad" baru mereka, yang sebenarnya tidak lebih dari sekedar taklid total kepada kepada "ijtihad" Orientalis. Tanpa memperhatikan perbedaan antara maslahat dan mafsadat yang mungkin ditimbulkan. "Anak-anak Orientalis" "merasa berdosa" jika Alquran ditulis dengan $q$ kecil karena huruf awal kata sandang al, sesuai dengn ijma' Orientalis, tidak boleh ditulis dengan huruf besar $A l$ kecuali di awal kalimat.

Dari segi legitimasi, ada sesuatu yang dilupakan. Benarkah ijma’ Orientalis dapat me-nasakh ijma' Indonesia jika orang menulis dalam bahasa Indonesia?. Dalam surat keputusan Bersama Menteri Agama dan Menteri Pendidikan dan Kebudayaan Republik Indonesia No. 158/1987 dan No.0543 b/U/1987 tertanggal 10 september 1987 (ditanda tangani tanggal 22 januari 1988). Ijma Indonesia ini memutuskan bahwa القران ditransliterasi menjadi Al-Qu'an. ${ }^{10}$

Kepribadian yang menjadi salah satu dasar pengalaman hukum fiqih menurut Hasbi tentulah yang dapat ditampung oleh pengertian 'urf yang dikehendaki oleh

10 Yudian Wahyudi, Ushul Fiqh Versus Hermeneutika Membaca Islam Dari Kanada dan Amerika (Yogyakarta: Pesantren Newesea Press, 2007), hlm. 52-54. 
Syara'. ${ }^{11}$ Maksudnya, adat-istiadat masyarakat Indonesia, baik yang bersifat umum maupun yang bersifat lokal dapat dijadikan sumber perbendaharaan hukum fiqih Islam setelah diadakan penelitian (ijtihad), mana diantara adat itu yang sesuai dengan syara' dan mana pula yang tidak. Setelah diadakan penelitian yang saksama menurut metode ijtihad, boleh jadi banyak adat kebiasaan masyarakat Indonesia ditolerir sebagai hukum fiqih.

Dapat dikatakan, Hasbi sebagai seorang ulama besar dizamannya memang cukup banyak memperhitungkan 'Urf (adat kebiasaan), khususnya kebiasaan masyarakat Indonesia dalam kaitannya dengan pengembangan hukum Islam. Boleh jadi, pandangannya ini didasari oleh pengamatannya pada literature klasik bahwa banyak benar hukum-hukum fiqih yang telah ditetapkan ulama berdasarkan 'Urf. Karena itu, Hasbi sendiri menghimbau kita untuk mempelajari sumper penetapan hukum Islam yang satu ini secara seksama agar kebiasaan masyarakat Indonesia yang dipandang sebagai al- 'Urfal-shahih .ditumbuh kembangkan. ${ }^{12}$

Pembaharuan pemikiran tentang Islam adalah hal yang harus dikerjakan terusmenerus agar tidak ketinggalan zaman, Akan tetapi Hasbi menekankan, makna pembaharuan bukanlah dengan meninggalkan nash. Yang dimaksud dengan pembahruan ialah memperbarui barang lama yang telah usang dengan mengembalikannya seperti keadaan semula. Hukum Islam telah berlalu beberapa masa, maka tentu ada sebagian yang telah dilekati kiambang dan lumut. Tugas pembaharu hukum ialah menghilangkan kiambang dan lumutyang telah menutupi kemurniannya, bukan untuk merombak atau menghancurkannya. Hukum Islam yang murni adalah

11 Menurut fakta sejarah, agama Islam yang dibawa oleh nabi Muhammad datang kepada masyarakat yang telah berbudaya. Masyarakat Arab ketika itu telah hidup dengan adat-istiadat mereka. Diantara adat-istiadat mereka ada yang dipandang buruk oleh Islam yang pada gilirannya dilarang. Misalnya kebiasaan minum khamar,judi, melakukan transaksi ribawi dan sebagainya. Disamping itu, ternyata ada pula adat-istiadat mereka yang dipandang baik oleh Islam dan boleh dikerjakan seterusnya. Misalnya sewa-menyewa, jual-beli dan sebagainya. hlm. 34 .

${ }^{12}$ Hasbi Ash-shiddieqy, Dinamika dan elastisitas Hukum Islam, (Jakarta: Bulan Bintang, 1976), 
sebagaimana tergambar dalam al-Qur'an, as-Sunnah, dan peninggalan ulama Salaf. Karena itu," Kita menentang setiap pembaruan yang membelakangi al-Qur'an dan asSunnah,"demikian kata Hasbi. ${ }^{13}$

Menurut Nurcholish Madjid, ide tentang perubahan dan perkembangan ini terlefleksikan dalam berbagai ide tentang bagaimana melaksanakan ajaran agama dalam masyarakat. Ini terkait dengan masalah kesadaran historis, yaitu kesadaran bahwa segala sesuatu mengenai tatanan hidup manusia ada sangkut pautnya dengan perbedaan zaman dan tempat. Teori Ushul Fiqh tentang nâsikh-mansûkh yaitu bahwa suatu ajaran atau ketentuan seperti hukum dapat dihapus dan digantikan oleh ajaran atau ketentuan baru yang lebih baik, menunjukkan adanya kesadaran historis yang sangat kuat pada ajaran Islam. Meskipun teori itu, seperti halnya dengan yang lain-lain, juga mengundang kontroversi dan polemic, namun sekali lagi bahwa sebagian besar Umat Islam menganutnya haruslah diperhatikan dengan sungguh-sungguh, mengingat implikasinya yang luas dan penting. Apalagi bagi mereka yang mendukungnya, seperti dianut Imam Syafi' $\hat{1}$, terdapat dalam firman Allah yang menunjukkan bahwa Allah memang menghapus ayat atau membuatnya terlupakan, untuk digantikan dengan ayat lainnya yang sepadan atau yang lebih(Lihat Q.S. Al-Baqarah: 106). ${ }^{14}$

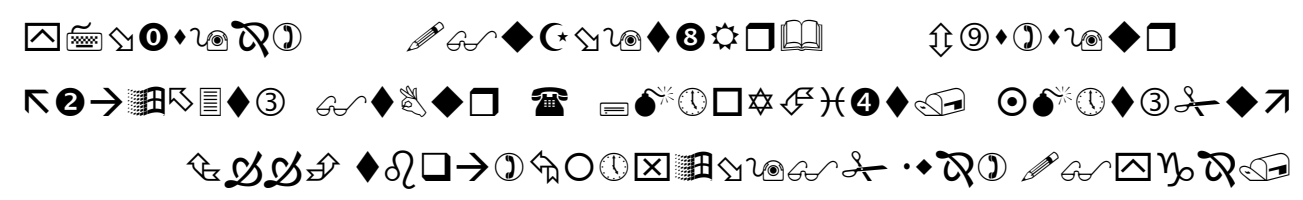

Dan Sesungguhnya Kami telah menurunkan kepadamu ayat-ayat yang jelas; dan tak ada yang ingkar kepadanya, melainkan orang-orang yang fasik.

Untuk menjustifikasi lokalitas Fiqh Indonesia, hasbi berpegang pada sejarah perkembangan fiqih (tarikh tasyri'). Tarikh tasyri', kata Hasbi, membuktikan bahwa

\footnotetext{
${ }^{13}$ Nourouzzaman Shiddiqi, Fiqih Indonesia Penggagas dan Gagasannya, (Yogyakarta: Pustaka Pelajar, 1997), hlm. 81-82.

${ }^{14}$ Nurcholish Madjid, Islam Doktrin dan Peradaban, (Jakarta: Yayasan Wakaf Paramadina, 1992), hlm. Xviii.
} 
fiqih lokal sudah muncul swejak awal penyebaran Islam melewati batas-batas Mekkah dan Madinah, Syafi'I di Baghdad (mazhab qadim) dan kemudian di Mesir (mazhab jaded), disamping mazhab Hambali di Baghdad, tentunya merupakan bagian dari contoh yang popular. Lokalitas mazhab-mazhab ini, menurut Hasbi dikarenakan perbedaan pendapat, tempat dan jiwa si mujtahid sendiri. Walaupun dilegitimasi oleh tarikh tasyri' (dirasat al-waqa'̂े) mengenai masyarakatIndonesia dengan system masyarakat lainnya yang sezaman. Studi ini harus menggunakan pendekatan sosiologi hukum dan studi hukum secara umum untuk melihat pengaruh dan kemampuan menyelesaikan kebutuhan-kebutuhan masyarakatnya.

Studi perbandingan ushul fiqh ini dilakukan dengan langkah sebagai berikut:

1. Mengkaji prinsip-prinsip yang dipegangi oleh setiap imam mazhab maupun masalah-masalah yang mereka perselisihkan dengan cara meneliti alasan-alasan mereka.

2. Mengkaji dalil-dalil yang mereka pegangi maupun yang diperselisihkan.

3. Mengkaji argument yang ditawarkan oleh masing-masing imam mazhab mengenai dalil-dalil yang diperselisihkan dan memilioh argument yang terkuat.

Langkah-langkah diatas, menurut Hasbi harus didahului dengan pendirian Fakultas Ushul fiqh atau paling tidak Jurusan ushul Fiqh (yang dalam konteks sekarang ini lebih tepat diselenggarakan di tingkat pascasarjana di lingkungan UIN). Bahkan Hasbi lebih yakin lagi bahwa Fiqh Indonesia akan sangat fleksibel jika didukung oleh perbandingan yang bersifat sistematis antara fiqh dan hukum adat Indonesia, antara fiqih dan sistem hukum Indonesia, antara fiqh dan Syari'at (agama-agama) lain dan antara fiqh dan sistem internasional.

Sebaliknya, jika problem yang dihadapi belum pernah diberikan pemecahannya oleh mujtahid-mujtahid terdahulu, maka Hasbi menganjurkan agar melakukan ijtihad 
bir-ra'y, yaitu menentukan hukum berdasarkan pada maslahat, kaidah-kaidah kuliah dan illat (kausa) hukum." 15

\section{SEJARAH SINGKAT ABDUL HAMID HAKIM DAN MUHAMMAD HASBI ASH SHIDDIEQY SEBAGAI PELOPOR USHUL FIQH MASUK DI INDONESIA}

\section{a. Sejarah Singkat Abdul Hamid Hakim}

Abdul Hamid Hakim dilahirkan pada tahun 1893, didesa sumpur ditepi danau Singkarak Sumatra barat, ayahnya bernama Abdul Hakim, seorang pedagang dikota Padang dan ibunya bernama Cari. Hakim adalah anak ketiga dari enam bersaudara. Kakaknya yang tertua bernama Muhammad Nur dan yang kedua adalah Husein. Sedangkan adik-adiknya adalah Hasan, Halim dan sofya.

Masa kecil Hakim dilewatkannya dipadang, tempat di mana ayahnya berusaha sebagai pedagang. Dikota ini pula Hakim menamatkan sekolah dasarnya. Ia tercatat dan dikenal sebagai anak yang berperilaku baik dan cerdas. Setelah menamatkan pendidikan di Sekolah Dasar, ia kembali ke kampungnya untuk sekolah di Madrasah yang khusus mempelajari Al-Qur'an.

Setelah menamatkan pelajaran al-Qur'an di kampungnya, pada tahun 1908 ia berangkat ke Sngayang di Batu Sangkar untuk belajar berbagai ilmu agama, seperti: nahwu, Shorof, Fiqih, Tauhid, Tafsir dab Hadis kepada Haji Muhammad Thaib Umar, salah seorang tokoh pembaharuan, guru dan ulama terkenal yang baru pulang dari Mekkah. Pilihan Hakim ini sangat tepat karena Thaib Umar inilah, melalui surau yang dikelolanya sejak tahun 1897, yang pertama kali melakukan perubahan materidan metode pengajaran ilmu-ilmu keagamaan dari corak lama ke corak bari di Sumatra barat. Walaupun Hakim hanya belajar selama dua tahun kepada Thaib Umar, namun

15 Yudian Wahyudi, Ushul Fiqh Versus Hermeneutika Membaca Islam Dari Kanada Dan Amerika ..., hlm. 41. 
dengan otaknya yang cerdas, setidak-tidaknya selama itu dia telah mengenali dan memahami ilmu-ilmu alat dan keagamaan dari berbagai kitab yang diajarkan gurunya itu.

Setelah belajar selama dua tahun kepada Thaib Umar, pada tahun 1910, yakni disaat usianya ke-16 tahun, Hakim berangkat ke Sungai Batang di Maninjau untuk belajar kepada Haji Abdul Karim Amrullah (Haji Rasul) ${ }^{16}$ yang baru saja mengajar di sana setelah pulang dari Mekkah. Dia terus mengikuti Haji Rasul ketika dua tahun kemudian, tahun 1912, gurunya pindah ke Padang karena diminta oleh sahabatnya, Abdullah Ahmad, untuk membantu mengelola al-Munîr, majalah Islam yang pertama di Indonesia. Ketika sang guru kemudian pindah ke Padang Panjang tahun 1914 karena diminta oleh masyarakat di sana untuk mengelola kembali pengajian Surau Jembatan Besi, dengan setia Hakim tetap mengikutinya. Tampaknya di bawah bimbingan Haji Rasul inilah, terutama ketika sang guru menekuni pengajian di Surau Jembatan Besi, Hakim belajar secara lebih intensis dan secara sistematis, sejalan dengan upaya sang guru untuk meningkatkan kualitas pendidikan untuk murid-muridnya yang terus bertambah, dengan mengubah system pengajian halaqah menjadi system klasikal pada tahun 1916.

Hakim merupakan murid yang paling disayangi oleh Haji Rasul, rukarena disamping cerdas dan berakhlak mulia, iapun mempunyai tekad dan kesungguhan yang luar biasa. Karena sesungguhnya itu tidak jrang dia menelaah kitab sampai larut malam dengan penerangan (lampu) seadanya. Sesungguhnya Hakim ini belajar ini didukung pula oleh kelengkapan buku-buku yang butuhkan yang selalu disediakan oleh ayahnya. Ketika ayahnya mengalami masa sulitt dalam perdagangannya, dan sempat ditahan karena hutang-hutangnya, maka hakim mengalami kesulitan untuk membeli buku-buku baru.

${ }^{16}$ Haji Abdul Karim Amrullah, salah seorang guru Hakim yang merupakan salah seorang Ulama Minangkabau terkenal di awal abad ini, selalu memuji ketekunan dan kepintaran Hakim. Hamka menyebutkan bahwa: "Haji Abdul Karim Amrullah kalau membicarakan orang-orang alim, dengan bersemangat dan mata berapi-api selalu memuji Hakim." Lengkapnya lihat Hamka, Ayahku (Jakarta: Umminda, 1982), hlm299-301. Sedangkan HAMKA sebagai seorang murid Hakim, sangat menyanjung dan mengakui keahlian gurunya ini, terutama dalam bidang ushul fiqh. 
Perjalanan hidup Hakim tidak terlepas dari perjuangan, terutama semenjak beliau memegang jabatan kepala sekolah Sumatra Thawalib Padang Panjang. Ia berjuang untuk melanjutkan pembaharuan yang telah dilakukan Abdullah Ahmad, Haji Muhammad Djamil Djambek, Haji Rasul dan Thaib Umar. Ia berjuang untuk membina dan selalu berusaha meningkatkan Thawalib. Ia selalu berada dan mengurus Thawalib, baik diwaktu susah maupun senang. Dan ia selalu membimbing dan melayani masyarakat menuju pemikiran dan pengalaman agama yang benar.

Ditengah-tengah beratnya perjuangan, Thawalib dan umat dalam keadaan sulit ketika peristiwa PRRI (Pemerintah Revolusioner Republik Indonesia) di Sumatra Barat, Hakim dipanggil sang pencipta, setelah sakit selama beberapa waktu. Beliau meninggal dunia pada hari senin tanggal 13 Juli $1959 \mathrm{M}$, atau 7 Muharram tahun $1379 \mathrm{H}$, di Padang Panjang, dalam usia kurang lebih 66 tahun.

Kepergian beliau, tidak hanya dirasakan dan ditangisi oleh keluarganya dan keluarga besar Sumatera thawalib, yaitu sekolah yang dibinanya selama lebih dari 40 tahun, tetapi juga oleh sekolah-sekolah lain dimana beliau mengajar atau menjadi tim penguji atau buku-bukunya yang dipakai, dan perguruan tinggi di mana beliau ikut menjadi dosen, guru besar, ataupun pimpinan. Disamping itu, mantan murid, teman seprofesi dan masyarakat luaspun sangat merasakan kehilangan dengan berpulangnya beliau. $^{17}$

\section{b. Murid-murid dan Karya Tulis Hakim}

1. Murid-murid Hakim

Kehidupan intelektual yang dijalani oleh Hakim dalam waktu yangt panjang, baik sebagai seorang guru, ulama, pemikir, maupun penulis telah membuahkan hasil yang tidak sedikit, dan itu merupakan warisan yang sangat berharga bagi generasi sesudahnya. Profesi guru dan pemimpin sekolah yang dijalaninya dengan penuh kesabaran dan keuletan dalam kurun waktu lebih kurang empat puluh tahun telah

\footnotetext{
${ }^{17}$ hhtp://biografi.blogsome.com, Akses tanggal 31 Desember 2009.
} 
menghasilkan ribuan lulusan, yang kemudian bergerak di berbagai bidang. Mereka ratarata muncul menjadi pejuang pembaharuan sesuai dengan kapasitas masing-masing. Di antara murid-murid hakim, terdapat sederetan nama yang kiemudian dikenal sebagai tokoh masyarakat di berbagai bidang, baik pada skala daerah, nasional, maupun internasional. Mereka antara lain sebagai berikut:

1) Haji Ahmad Rasyid Sutan Mansur (1895-1985) ${ }^{18}$

2) Prof. Dr. HAMKA (1908-1981)

3) Haji Zainal Abidin Ahmad (1911-1983)

4) Haji Mansoer Daoed Datuk Palimo Kayo (1905- 1985)

5) Duski Samad (1905-1985)

6) Rasuna Said (1910-1962)

7) Nazaruddin Latif (1916-1972)

8) Haji Mawardi Muhammad (1911-1995)

9) Prof. Ali Hasyimi (1908-1997)

10) Rahmah El-Yunusiyyah (1900-1969)

11) Haji Salim Amany (lahir tahun 1908)

Disamping nama-nama diatas, berikut ini akan disebutkan beberapa nama tokoh masyarakat yang pernah menjadi murid Hakim, tanpa memberikan uraian rinci tentang riwayat hidup mereka. Mererka antara lain: Prof. Dr. Mukhtar Yahya, yang pernah menjadi direktur Islamic Collage, sekolah yang cukup terkenal di Padang sebelum kemerdekaan, dan menjadi Guru Besar PTAIN dan IAIN Yogyakarta. K.H. Zarkasyi, pendiri dan pemimpin Pondok Pesantren Modern Gontor. Prof. Dr. Khatib Khuzwein, Sekretaris Jenderal Departemen Agama Republik Indonesia (1996-1998) dan Staf Ahli Menteri Agama RI (sejak tahun 1998). Prof. Dr. Amir Syarifuddin, mantan Rektor IAIN Imam Bonjol, Padang (1983-1992), ketua MUI Sumatera Barat (1990-sekarang), ketua Umum BAZIZ Tingkat I Sumatera Barat (1993-Sekarang), dan anggota MPR-RI

${ }^{18}$ Tentang Buya AR. Sutan Mansur, antara lain dapat dilihat HAMKA, Ayahku,hlm. 306-310. Disamping itu lihat juga Rusydi HAMKA,'Peranan Sutan Mansur dalam Kebangkitan Islam di Indonesia," dalam panji Masyarakat, Nomor: 464/1985. 
(periode 1992-1998). H. Ghazali Amna, anggota DPR-RI dari fraksi Partai Persatuan Pembangunan periode 1988-1993 dan periode 1993-1998. H. Harun Yunus, tokoh PSII, ulama Sumatera Barat yang sekarang ikut sebagai pengurus Yayasan Thawalib. H. Hasan Ahmad, mantan pimpinan Muhammadiyyah Sumatera Barat. H. Ahmad Soufyan, guru Thawalib dan sekampung dengan hakim. H. Abbas Usman, guru Thawalib dan sekampung dengan Hakim.

\section{c. Karya-karya Hakim}

Kegiatan tulis-menulis telai mulai ditekuni oleh Hakim semenjak ia dipercaya menjadi wakil direktur dan sekaligus pengarang pada majalah al-Munir al-Manar yang diterbitkan di Padang Panjang pada tahun 1918, dibawah pimpinan Zainuddin Labai ElYunusiy.

Lewat majalah ini, Hakim berusaha mengasah kemampuan menulis yang dimilikinya. Diantaranya dengan menjawab berbagai pertanyaan yang diajukan oleh pembaca, terutama yang menyangkut bidang Fikih dan Ushul Fikih.Dan masih banyak lagi karya beliau yang berkaitan dengan fiqih dan Ushul Fiqh.

\section{Sejarah Singkat Muhammad Hasbi Ash Shiddieqy \\ a. Kisah Hidup Muhammad Hasbi Ash Shiddieqy}

Muhammad Hasbi Ash Shiddieqy dilahirkan di Lhokseumawe, Aceh Utara, pada Maret 1904, di tengah-tengah keluarga ulama pejabat. Ibunya, Tengku Amrah, adalah putri Tengku Abdul Aziz, pemangku jabatan Qadli Chik Maharaja Mangkubumi. Ia juga keponakan Abdul Jalil, berjuluk Tengku Chik di Awe Geutah, seorang ulama pejuang yang bersama Tengku Tapa bertempur di Aceh melawan Belanda. Ayah Hasbi, al-Haj Tengku Muhammad Husen ibn Muhammad Su'ud, menduduki jabatan Qadli

Chik di Simeuluk Samalanga. Tengku Chik di Simeuluk adalah keturunan Faqir Muhammad (Muhammad al-Ma'sum). 
Hanya enam tahun Hasbi mengenyam belaian kasih ibunya. Pada tahun 1910, bertepatan dengan tahun gugurnya Pocut Meutia, ibunda Hasbi meninggalkan dunia yang fana ini. Hasbi menjadi piatu. Dua tahun beliau diasuh oleh Tengku Syamsiah yang lebih akrab dipanggil Tengku Syam, saudara ibunya yang tidak berputra. Tengku Syam wafat pada tahun 1912, bertepatan dengan tewasnya Tengku barat,

Faqir Muhammad, sebelum berangkat ke Aceh adalah raja di Negeri Mangiri di Malabar. Di Malabar, Islam telah tersiar sejak masa Nabi dan dilakukan oleh para penyiar Islam yang datang khusus untuk berdakwah. Faqir Muhammad berangkat ke Aceh bersama Syaikh Ismail utusan Syarif Makkah, untuk berdakwah ke Samudra Pasai, sekitar tahun 1270-1275.

Muhammad Su'ud, kakek Hasbi telah separuh baya ketika perang Aceh meletus. Selaku seorang pejuang dan pendidik, pemimpin dayah yang diwarisi dari leluhurnya,ia tergugah oleh kesengsaraan yang terjadi disekelilingnya itu. Para ulama dan pemimpin dayah, seperti Syaikh Saman Tengku Chik di Tiro, Syaikh Abbas Tengku Chik Kuta Karang, Habib Berahim Samalanga, terjun ke medan laga melawan kaphe. Dayahnya sendiri telah hancur diterjang peluru kaphe pada tahun 1880. Su'ud berpendapat, tugas membela Negara memang kewajiban utama, namun mempersiapkan kader ulama calon pemimpin umat tidak boleh dialpakan. Maka, ia menyuruh anaknya, Muhammad Husein, ayah Hasbi, keluar dari Bate Ilik pergi menuntut ilmu ketempat lain.

Husein mengambil jalan berjihad dengan mengajar. Atas bantuan mertuanya, ia mendirikan sebuah rangkang. Karena sudah naik haji dan belajar pada guru-guru di Makkah, rangkangnya segera berkembang menjadi dayah. Selang beberapa waktu, ia pun dilantik sebagai QadliChik, menggantikan kedudukan mertuanya yang telah wafat.

Hasbi adalah keturunan ketiga puluh tujuh dari Abu Bakar ash-Shiddieq. Itulah sebabnya, sejak tahun 1925, atas saran Syaikh Muhammad ibn Salim al-Kalali, ia menggunakan sebutan ash-Shiddieqy di belakang namanya sebagai nama keluarga. 


\section{b. Pendidikan Muhammad Hasbi Ash Shiddieqy}

Hasbi telah khatam mengaji al-Qur'an dalam usia delapan tahun. Satu tahun berikutnya ia belajar qiraah dan tajwid serta dasar-dasar tafsir dan fiqh pada ayahnya sendiri. Permintaan Kontrolir Lhokseumawe kepada ayah Hasbi agar ia dimasukan ke sekolah gubernemen ditolaknya ia kwatir anaknya akan dipengaruhi oleh pemikiran Nasrani. Ayahnya menganjurkan Hasbi menjadi ulama. Karena itu, ia harus dikirim belajar ked ayah. Pertimbangannya bukan saja untuk meneruskan tradisi leluhur tetapi juga kedudukan dan penghargaan terhadap ulama memang tinggi di mata masyarakat Aceh.

Selama delapan tahun lamanya Hasbi nyantri dari suatu dayah ke dayah yang lain. Pada tahun 1912, Hasbi dikirim nyantri ke dayah Tengku Chik di Peyeung yang nama pendirinya Abdullah untuk belajar bahasa Arab, khususnya nahwu dan sharaf. Setelah pengetahuan dasar disara cukup, pada tahun 1916 ia pergi merantau atau nyantri ked ayah Tengku Chik di Tanjungan Barat yang bernama Idris, di Samalanga. Dayah ini adalah salah satu dayah terbesar dan terkemuka di Aceh utara yang mengkhususkan diri dalam pelajaran ilmu fiqh. Dua tahun beliau nyantri did ayah ini, setelah itu Hasbi pindah nyantri ked ayah Tengku Chik di Kreungkale, yang bernama Hasan. Selama dua tahun beliau nyantri di kreungkale di Aceh Rayeuk untuk belajar hadis dan memperdalam fiqh.

Pada tahun 1920, dari Tengku Chik Hasan Kreungkale, ia memperoleh Syahadah sebagai pernyataan bahwa ilmunya telah cukup dan berhak membuka dayah sendiri. Ia pulang ke Lhokseumawe dengan perasaan belum puas. Sepulangnya dari Kreungkale, Hasbi berjumpa dengan Syaikh Muhammad ibn Salim al-Khalali, seorang yang termasuk kelompok kaum pembaharu pemikiran Islam di Indonesia, yang bermukim di Lhokseumawe. Melalui Syaikh al-Kalali ia mendapat kesempatan membaca kitab-kitab yang ditulis oleh pelopor-pelopor Kaum Pembaru Pemikiran Islam. Melalui Syaikh alKalali pula ia berkesempatan membaca majalah-majalah yang menyuarakan suara-suara pembaharuan yang diterbitkan di Singapura. 
Lebih setahun Hasbi setelah kembali dari menghadiri KMI (Kongres Muslim Indonesia) XV yang berlangsung di Yogyakarta 20-25 Desember 1949, Hasbi mendapat tawaran dari menteri Agama, KH Wahid Hasyim, untuk menjadi tenaga pengajar pada Perguruan Tinggi Agama Islam Negeri (PTAIN).

Hasbi yang memperkaya dirinya dengan ilmu pengetahuan secara otodidak, menjelang wafatnya memperoleh dua gelar Doctor Honoris Causa karena jasa-jasanya terhadap perkembangan Perguruan Tinggi Islam di Indonesia dan Perkembangan Ilmu Pengetahuan Keislaman. Yang satu diperoleh dari Universitas Bandung (Unisba) pada tanggal 22 Maret 1975, dan yang satu lagi dari Institut Agama Negeri (IAIN) Sunan Kalijaga Yogyakarta pada tanggal 29 Oktober $1975 .{ }^{19}$

\section{E. KESIMPULAN}

Ushul Fiqh masuk di Indonesia tepatnya pada abad ke-17, oleh Abdul Rauf AsShiddiqymenerjemahkan bahasa Arab ke bahasa Melayu. Dan pada abad ke-18 M. Hamzah Fanzuri menulis ushul Fiqh dari bahsa Arab dalam bahasa lokal. Ushul Fiqh masuk di Indonesia dengan tokoh-tokohnya sebagai berikut:

1. Syeikh Abdul Karim Amrullah, menulis Ushul Fiqh ke dalam bahasa Indonesia tetapi naskahnya tidak ditemukan.

2. Abdul Hamid Hakim menulis Ushul Fiqh dalam bahasa Indonesia.

3. Ahmad Hasan, beliau banyak menyinggung tentang Ushul Fiqh tetapi bukunya tidak di temukan.

4. Hasbi As-Siddieqy, beliau banyak menulis tentang ushul Fiqh.

Sejauh yang telah dipaparkan dalam tulisan di atas, maka dapat ditegaskan beberapa hal sebagai berikut:

${ }^{19}$ hhtp://biografi.blogsome.com, Akses tanggal 31 Desember 2009 
1. Melalui perjuangan eksistensi, ushul fiqh berhasil eksis sepanjang sejarah perkembangan hukum di Indonesia dan mewarnai sistem hukum nasional Indonesia;

2. Disamping beberapa peluang, dimasa-masa yang akan datang, Uhsul fiqh khususnya masih menghadapi berbagai hambatan. Untuk itu perlu diupayakan langkah-langakah strategis berupa, optimalisasi fungsi ijtihad dan optimalisasi fungsi komunikasi;

3. Jika peluang dan kekuatan yang ada dapat dimanfaatkan secara optimal, hambatan dan kelemahan dapat dieliminir dan dicarikan solusinya. 


\section{Daftar Pustaka}

Abd. Al-Majid al-Syarfi, Al-Islam al-Hadasah, cet. Ke-3, Tunisia: Dar Al-Janub li AlNasyr, 1998.

Abdul Wahhab Khallaf, Ilmu Uhsul Fiqh Semarang: Dina Utama: 1994.

Amir Syarifuddin, Ushul Fiqh Jilid 1, Jakarta: Logos Wacana Ilmu: 1997.

Yudian Wahyudi, Ushul Fiqh Versus Hermeneutika Membaca Islam Dari Kanada Dan Amerika, Yogyakarta: Pesantren Newesea Press, 2007.

HAMKA, Ayahku, Jakarta: Umminda, 1982.

Hasbi Ash-shiddieqy, Dinamika dan elastisitas Hukum Islam, Jakarta: Bulan Bintang, 1976.

hhtp://biografi.blogsome.com.

hhtp://dolla.blogsome.com.

Nasrun Harun Ushul Fiqh 1 ,Jakarta: Logos Wacana Ilmu: 1997.

Nurcholish Madjid, Islam Doktrin dan Peradaban, Jakarta: Yayasan Wakaf Paramadina, 1992.

Nourouzzaman Shiddiqi, Fiqih Indonesia Penggagas dan Gagasannya, Yogyakarta: Pustaka Pelajar, 1997. 